\title{
PERBANDINGAN EFEKTIFITAS MASSAGE DAN KOMPRES HANGAT TERHADAP NYERI PERSALINAN KALA 1 FASE AKTIF
}

\author{
Yenny Safitri \\ Dosen Prodi Sarjana Keperawatan FIK Universitas Pahlawan Tuanku Tambusai \\ Email: yennysafitri37@yahoo.co.id
}

\begin{abstract}
In the primitive societies, the childbirth is longer and pain, while the people who have advanced $7-14 \%$ childbirth without pain and $90 \%$ with pain. The purpose of this study was to compare the effectiveness of massage and warm compresses to the first stage of childbirth pain of active phase in Maternity Clinic Ernita years 2015. The clinical research design is quasi-experimental comparison group are time series design. The population in this study are all women giving birth at the maternity clinic Ernita in September of 2015 as many as 45 people. The sample was selected by accidental sampling technique with the study subjects were 30 people who were divided into 2 groups of intervention. The technique of collection data is experiments on the mother inpartu time 1 active phase. Analysis of the data used is the Independent t- test. The results showed faster massage in reducing pain intensity first stage of childbirth is the active phase. The conclusions in this study are more effective massage to reducing pain of childbirth on the active phase.
\end{abstract}

Kata kunci : Kompres Hangat, Massage, Nyeri Persalinan

\section{PENDAHULUAN}

Nyeri persalinan merupakan kondisi berupa perasaan yang tidak menyenangkan, apabila tidak diatasi dengan baik akan menimbulkan masalah lain yaitu meningkatnya kecemasan, karena kurangnya pengetahuan dan belum ada pengalaman pada ibu primigravida saat menghadapi persalinan sehingga produksi hormon adrenalin meningkat dan mengakibatkan vasokonstriksi yang menyebabkan aliran darah ibu ke janin menurun. Janin akan mengalami hipoksia sedangkan ibu akan mengalami persalinan lama dan dapat meningkatkan tekanan sistolik dan diastolik (Maryunani, 2010).

Sifat nyeri persalinan sangat subjektif karena perasaan nyeri berbeda pada setiap orang dalam hal skala atau tingkatannya, dan hanya orang tersebutlah yang dapat menjelaskan atau mengevaluasi rasa nyeri yang dialaminya. Bagian tubuh yang sering diderita keluhan nyeri adalah leher, tangan, kaki, dan daerah pinggang. Selain obat dan terapi, untuk pertolongan pertama bisa dilakukan dengan masase dan kompres hangat untuk membantu pengurangan nyeri persalinan (Bandiyah, 2009).

Manajemen nyeri persalinan dapat diterapkan secara non farmakologis dan farmakologis. Pendekatan secara non farmakologis tanpa penggunaan obatobatan seperti relaksasi, masase, akupresur, akupunktur, kompres panas atau dingin dan aromaterapi, sedangkan secara farmakologis melalui penggunaan obat-obatan. Manajemen nyeri non farmakologis lebih aman, sederhana dan tidak menimbulkan efek merugikan serta mengacu kepada asuhan sayang ibu, dibandingkan 
dengan metode farmakologi yang berpotensi mempunyai efek yang merugikan (Mander, 2004).

Dalam persalinan, masase membantu ibu lebih rileks dan nyaman selama persalinan. Ibu yang yang di masase selama tahapan persalinan yang dilakukan oleh petugas kesehatan, keluarga pasien ataupun pasien itu sendiri akan lebih bebas dari rasa sakit, karena masase meransang tubuh melepaskan senyawa endorphin. Banyak bagian tubuh ibu bersalin yang dapat di masase, seperti kepala, leher, punggung dan tungkai. Saat memijat, pemijat harus memperhatikan respon ibu apakah tekanan yang diberikan sudah tepat (Meiliasari, 2004).

Teknik Effleurage merupakan metode masase yang cukup efektif dalam membantu mengurangi nyeri pinggang persalinan dan relatif aman karena tidak ada efek samping yang ditimbulkan. Prinsip metode ini adalah mengurangi ketegangan ibu sehingga ibu mersa nyaman dan rileks menghadapi persalinan. Metode ini juga dapat meningkatkan stamina untuk mengatasi rasa nyeri dan tidak menyebabkan depresi pernafasan pada bayi yang dilahirkan (Maryunani, 2010). Kompres hangat meningkatkan suhu lokal, sirkulasi, dan metabolisme jaringan. Kompres hangat mengurangi spasme otot dan intensitas nyeri dalam persalinan. Kompres hangat juga mengurangi, melawan dan menghindar respon ibu terhadap nyeri persalinan kala 1. Pemberian kompres panas lokal atau selimut hangat akan menenangkan ibu bersalin, menghilangkan sensasi rasa nyeri, merangsang peristaltic usus, pengeluaran getah radang serta memberikan ketenangan dan kenyamanan pada ibu inpartu (Simkin, 2005).

Penelitian Ratih (2010) yang bertujuan untuk mengetahui pengaruh metode masase yaitu Massage effleurage terhadap penurunan intensitas nyeri persalinan dengan menggunakan desain quasi eksperimen memberi hasil yang signifikan antara intensitas nyeri sebelum dan sesudah dilakukan intervensi pada kala I persalinan, sehingga disimpulkan bahwa masase ini efektif mengurangi intensitas nyeri persalinan. Sedangkan, penelitian Sari (2010), bertujuan untuk mengukur intensitas penurunan nyeri dengan metode kompres hangat pada ibu bersalin kala I fase aktif. Desain yang digunakan adalah quasi eksperimen yang bersifat one group pretes dan postes. Dengan besar sample dua-dua orang, analisa data yang digunakan adalah uji $\mathrm{t}$-dependen. Dari hasil penelitian diperoleh kesimpulan bahwa kompres hangat mempunyai pengaruh terhadap pengurangan nyeri persalinan.

Survei awal yang dilakukan pada 20 September 2015, terdapat $45 \mathrm{ibu}$ bersalin bulan September tahun 2015 . Hasil wawancara dengan beberapa bidan di Klinik Ernita menyatakan bahwa untuk mengurangi rasa nyeri, bidan menyuruh ibu untuk mencari posisi yang nyaman dan menarik nafas selama kontraksi, dan ibu melakukan pengaturan pernafasan dan menguatkan hatinya dengan harapan rasa sakit itu akan hilang pada saat ia melihat bayinya nanti, dan ada beberapa ibu bersalin yang mengatakan perasaan takut akan nyeri memang ada, tetapi apabila nyeri tersebut datang bidan menyuruh ibu untuk mengalihkan perhatian terhadap nyeri dengan berjalan - jalan .

Berdasarkan fenomena diatas, maka penulis tertarik untuk menulis penelitian tentang “ Perbandingan Efektifitas Masase dan Kompres Hangat terhadap Nyeri Persalinan Kala 1 Fase Aktif di Klinik Ernita Pekanbaru Tahun 2015". 


\section{BAHAN DAN METODE}

Penelitian ini menggunakan desain penelitian quasi- eksperimen yang bersifat time series group comparison design. Penelitian ini dilakukan di Klink Bidan Ernita Pekanbaru. Populasi dalam penelitian ini adalah seluruh ibu inpartu kala I fase aktif. Sampel dalam penelitian ini adalah seluruh ibu bersalin di Klinik Ernita dari tanggal September - 21 Oktober 2015 yaitu sebanyak 30 orang. Teknik pengambilan sampel menggunakan pendekatan secara accidental samplin. Peneliti menjelaskan kepada responden tentang tujuan dan manfaat penelitian, prosedur penelitian, serta pengukuran skala nyeri. Selanjutnya meminta kesediaan responden untuk mengikuti penelitian dan menandatangani lembar persetujuan (informed consent). Peneliti mengkaji skala nyeri yang dirasakan pada kedua kelompok intervensi. Peneliti mengkaji skala nyeri pada kelompok masase terlebih dulu, setelah

\section{HASIL PENELITIAN}

Hasil penelitian yang dilakukan kepada ibu bersalin di Klinik Ernita Pekanbaru ditemukan bahwa dari 30 responden untuk karakteristik umur terdapat komposisi umur yang merata yaitu kelompok umur dewasa awal masing-masing kelompok intervensi adalah 15 orang (100\%), sedangkan 30 responden untuk kelompok paritas terdapat komposisi paritas yang tidak merata yaitu kelompok primipara masing-masing untuk kelompok intervensi adalah 15 responden $(86,7 \%)$ dan kelompok multipara masing-masing untuk kelompok intervensi adalah 2 responden $(13,3 \%)$.

Menurut asumsi peneliti, umur merupakan salah satu faktor yang mempengaruhi nyeri persalinan, karena kondisi nyeri hebat pada dewasa muda dapat dirasakan sebagai keluhan ringan pada dewasa tua, orang dewasa tua mengalami penurunan persepsi sensori stimulus, serta peningkatan ambang kelompok masase terkumpul, maka selanjutnya peneliti melakukan teknik masase pada kelompok intervensi. Selanjutnya peneliti mengkaji skala nyeri pada kelompok kompres hangat, setelah kelompok kompres hangat terkumpul, maka peneliti melakukan teknik kompres hangat pada kelompok intervensi. Peneliti mengkaji perbandingan skala nyeri antara kelompok masase dan kelompok kompres hangat, setelah didapatkan perbandingan intensitas nyeri setelah di berikan teknik masase dan kompres hangat maka peneliti dapat menyimpulkan perbandingan masase dan kompres hangat terhadap intensitas nyeri persalinan kala 1 fase aktif. Untuk menganalisis data secara bivariat, pengujian data dilakukan dengan uji $t$ independen yaitu uji statistik (T-Test) untuk mengukur perbandingan skala nyeri setelah dilakukan masase dan kompres hangat pada kelompok intervensi.

nyeri. Selain itu, paritas juga dapat mempengaruhi nyeri persalinan kala 1 fase aktif karena kehamilan pertama sensori nyeri umumnya dirasa sangat besar terutama oleh ibu baru menjalani persalinan pertama dibandingkan dengan ibu yang menjalani persalinan multipara dan grandemultipara.

Kecemasan akan meningkatkan respon individual terhadap rasa sakit, ketidaksiapan menjalani proses melahirkan, dukungan dan pendamping persalinan, takut terhadap hal yang tidak diketahui, pengalaman buruk persalinan yang lalu juga akan menambah kecemasan, sehingga menimbulkan peningkatan rangsang nosiseptif pada tingkat korteks serebral dan peningkatan sekresi katekolamin yang juga meningkatkan rangsang nosiseptif pada pelvis karena penurunan aliran darah dan terjadi ketegangan otot.

Pengaruh nilai rata-rata intensitas nyeri responden $\mathrm{s}$ yang dilakukan kompres hangat lebih rendah dari yang 
dilakukan masase. Hasil uji $t$ Independent diketahui bahwa terdapat perbandingan efektifitas masase dan kompres hangat dalam menurunkan intensitas nyeri dalam persalinan kala 1 fase aktif.

Penelitian Ratih (2010) yang bertujuan untuk mengetahui pengaruh metode masase yaitu Massage effleurage terhadap penurunan intensitas nyeri persalinan dengan menggunakan desain quasi eksperimen memberi hasil yang signifikan antara intensitas nyeri sebelum dan sesudah dilakukan intervensi pada kala I persalinan, sehingga disimpulkan bahwa masase ini efektif mengurangi intensitas nyeri persalinan.

Penelitian Sari (2010), bertujuan untuk mengukur intensitas penurunan nyeri dengan metode kompres hangat pada ibu bersalin kala I fase aktif. Desain yang digunakan adalah quasi eksperimen yang bersifat one group pretes dan postes dengan besar sampel dua-dua orang. Analisa data yang digunakan adalah uji $\mathrm{t}$-dependen, dari hasil penelitian diperoleh kesimpulan bahwa kompres hangat mempunyai pengaruh terhadap pengurangan nyeri persalinan.

Hal ini sesuai dengan pernyataan Lowe (2007), melahirkan adalah asosiasi dan proses fisiologis dan nyeri akut, pengalaman rasa sakit atau melahirkan hasil dari respon fisiologis dan psikologis serta interpretasi individu terhadap stimulus.

Nyeri adalah sesuatu yang bersifat universal dan merupakan keluhan yang bersifat umum pada sebagian besar manusia. Keberadaan nyeri merupakan isyarat, tanda, dan bahaya yang terjadi pada manusia dan juga ditafsirkan sebagai ancaman atau gangguan terhadap integritas organisme yang bersangkutan. Nyeri juga dapat

\section{SIMPULAN DAN SARAN}

1. Karakteristik demografi responden di Klinik Ernita Pekanbaru diketahui mengganggu hubungan personal dan mempengaruhi makna kehidupan seseorang (Potter \& Perry, 2005).

Menurut Simkin, (2007) nyeri persalinan kala-satu adalah akibat dilatasi seviks dan segmen uterus bawah dengan distensi lanjut, peregangan, dan trauma pada serat otot dan ligamen. Faktor penyebab nyeri persalinan adalah tekanan kepala bayi dan meregangnya jaringan ikat pendukung rahim dan sendi panggul selama kontraksi dengan turunnya kepala bayi, tekanan pada saluran kemih, kandung kemih, dan anus, dan meregangnya otot-otot dasar panggul dan jaringan vagina.

Stimulasi kulit dengan teknik masase effleurage menghasilkan impuls yang dikirim lewat serabut saraf besar yang berada di permukaan kulit, serabut saraf besar ini akan menutup gerbang sehingga otak tidak menerima pesan nyeri karena sudah diblokir oleh stimulasi kulit dengan teknik ini, akibatnya persepsi nyeri akan berubah. Selain meredakan nyeri, teknik ini juga dapat mengurangi ketegangan otot dan meningkatkan sirkulasi darah di area yang terasa nyeri (Bobak, 2004).

Pemberian kompres hangat bisa menyebabkan respon sistemik dan respon lokal. Stimulasi ini mengirimkan impuls-impuls dari perifer ke hipotalamus yang kemudian menjadi sensasi temperature tubuh secara normal. Kompres hangat juga memberikan rasa hangat pada daerah tertentu dengan menggunakan cairan atau alat yang menimbulkan hangat pada bagian tubuh yang memerlukan. Tindakan ini selain untuk melancarkan sirkulasi darah juga untuk menghilangkan rasa sakit, merangsang peristaltik usus, pengeluaran getah radang menjadi lancar, serta memberikan ketenangan dan kesenangan pada klien (Simkin, 2005).

bahwa karakteristik umur terdapat komposisi umur yang merata yaitu kelompok umur dewasa awal dan 
kelompok paritas terdapat komposisi paritas yang tidak merata yaitu kelompok primipara dan multipara.

2. Rata-rata penurunan intensitas nyeri persalinan setelah mendapatkan kompres hangat lebih rendah dari

\section{KEPUSTAKAAN}

Abdul, Muhith., 2011. Metodologi Penelitian Kesehatan. Yogyakarta: Nuha Medika

Arikunto, 2010. Prosedur Penelitian Suatu Pendekatan Praktek. Jakarta : Rineka Cipta

Bandiyah, S,. 2009. Kehamilan, Persalinan dan Gangguan Kehamilan. Yogyakarta : Nuha Medika

Bobak, 2004,. Lowdermilk and Jansen, Keperawatan Maternitas, Jakarta : Penerbit Buku Kedokteran EGC

Depkes RI,. 2015,Visi dan Misi Indonesia Sehat. (online), (http://www.depkes.go.id,2001., Diakses pada tanggal 03 September 2015, jam 10.00 WIB)

Eniyanti, 2012. Asuhan Kebidanan pada Ibu Bersalin, Yogyakarta : Pustaka Pelajar

Gadysa, G., 2015. Persepsi Ibu Tentang Metode Masase, (http://luluvikar.wordpress.com. Diakses pada tanggal 30 Agustus 2015, jam 10.30 WIB)

Hidayat, Aziz Alimul,. 2007. Metode Penelitian Kebidanan \& Teknik Analisa Data, Jakarta: Salemba Medika

Hidayat, Aziz Alimul,. 2007. Ketrampilan Dasar Praktek Klinik Untuk Kebidanan, Jakarta: Salemba Medika

Luknis Sabri, Statistik Kesehatan, Jakarta: Rajawali Pers, 2011.

Mander, R, Nyeri Persalinan, Alih Bahasa: dr. Bertha Sugiarto, Jakarta,Penerbit Buku Kedokteran EGC,2004.

Maryunani, A, Nyeri dalam Persalinan: Teknik dan Cara Penanganannya, Jakarta,Trans Info Media,2010. pada rata-rata penurunan intensits nyeri persalinan pada kelompok masase.

3. Teknik massage lebih efektif dalam menurunkan nyeri persalinan

Meiliasari, M., dan Danuatmaja, B. Persalinan Normal Tanpa Rasa Sakit, Jakarta,Puspa Swara,2004.

Notoatmodjo, Soekidjo, Metodologi Penelitian Kesehatan, Jakarta,Rineka Cipta,2012.

Nursalam, Konsep dan Penerapan Metodologi Penelitian Ilmu Keperawatan, Jakarta,Salemba Medika,2008.

Perry \& Potter, a. Buku Ajar Fundamental Keperawatan ; Konsep, Proses, dan Praktik, Volume 1, Edisi 4, Jakarta,Penerbit Buku Kedokteran EGC.2005.

Prawirohardjo, S. Ilmu Kebidanan, Yogyakarta,Yayasan Bina Pustaka Sarwono Prawirihardjo,2005.

Price, A, Sylvia, Patofisiologi, Jakarta: EGC,2005

Profil Dinas Kesehatan Riau, Data AKI dan $\boldsymbol{A K B}$, Diakses pada tanggal 02 September 2015, dari http://www.profildinkes.go.id,2011.

Saryono, Metodologi Penelitian Kebidanan DIII, DIV, SI dan S2, Yoyakarta, Nuha Medika,2010.

Simkin, P., Ancheta, R, Buku Saku Persalinan, Jakarta,EGC,2011.

Smeltzer, Suzanne C, Buku Ajar Keperawatan Medikal Bedah Brunner \& Suddarth, edisi 8 Vol 1.alih bahasa Agung Waluyoet all Jakarta: Buku Kedokteran EGC,2002.

Sulistyaningsih, Metodologi Penelitian Kebidanan Kuantitatif dan Kualitatif, Yogyakarta, Graha Ilmu,2011.

Walsh, V. L. Buku Ajar Kebidanan Komunitas, Jakarta, EGC, 2007. 
